\title{
PENGARUH PEMBERIAN DOSIS EM4 DAN DOLOMIT TERHADAP HASIL DARI PUPUK ORGANIK GRANUL
}

\author{
Bisma Prabawa Adikara ${ }^{1)}$ dan Sri Widyastuti ${ }^{1)}$ \\ ${ }^{1)}$ Program Studi Teknik Lingkungan, Fakultas Teknik Sipil dan Perencanaan (FTSP) \\ Universitas PGRI Adi Buana Surabaya \\ Email: sriwidyastuti@unipasby.ac.id
}

\begin{abstract}
Abstrak
Limbah pertenakan adalah salah satu penyebab yang dapat mencemari lingkungan sekitar dan tanah. Sampah atau limbah saat ini menjadi persoalan pokok di kota-kota besar, khususnya di Indonesia. Saat ini limbah peternakan banyak dan melimpah di seluruh Indonesia yang bisa membuat tercemarnya lingkungan sekitar ataupun tanah yang subur sehingga dampaknya sangat berbahaya bagi masyarakat. Feses dapat diolah menjadi produk yang lebih bermanfaat sehingga memiliki nilai ekonomi. Bahkan, limbah dapat dimanfaatkan menjadi produk baru (waste to product) dan menjadi energi (waste to energy). Pupuk organik seperti pupuk kandang ayam merupakan salah satu jenis bahan organik yang memiliki keunggulan dalam menyediakan hara bagi tanaman terutama unsur hara makro dan mikro walaupun dalam jumlah relatif sedikit. Penelitian ini bertujuan untuk mengetahui pengaruh pemberian dosis EM4 dan dolomit terhadap hasil dari pupuk organik granul. Hasil dari penelitian ini yaitu pada perlakuan pertama, kedua, ketiga dan keempat dengan masing-masing 3 kali replikasi menhasilkan parameter nitrogen, phosphor dan kalium memenuhi syarat permentan no 70 tahun 2011. Sedangkan untuk parameter karbon dan $\mathrm{C} / \mathrm{N}$ rasio pada perlakuan pertama dan kedua memenuhi persyaratan sedangkan perlakuan ke ketiga dan keempat tidak memenuhi persyaratan permentan no 70 tahun 2011.
\end{abstract}

Kata kunci: feses ayam, pupuk granul, kompos

\begin{abstract}
Farm waste is causing environmental and soil contamination. Trash and waste are now becoming main issues in large cities, particularly in Indonesia. Nowadays, farm waste is plentiful and abundant in Indonesia which can contaminate both its surrounding environment and fertile soil so thus it causes harm effects to community. Feces are able to be transformed into beneficial products with economical benefits. Moreover, waste can be transformed into new products (waste to product) and becoming an energy (waste to energy). Organic fertilizer like chicken manure fertilizer is organic materials which has advantage in supplying both macro and micro nutrients to plants but in relatively small quantities. This study aimed to determine the effects of EM4 doses and dolomites addition toward granular organic fertilizer results. The results of this study were; on the first, second, third and fourth treatment with three replications of each treatment gained the parameters of nitrogen, phosphor, and potassium which met the standards of Permentan No. 7/2011. However, the parameters of $C / N$ ratio gained on first and second treatment met the standards while on third and forth treatment did not meet the standards.
\end{abstract}

Keywords : chicken feces, fertilizer, granule, compost 


\section{PENDAHULUAN}

Lahan merupakan salah satu faktor penting penentu keberhasilan kegiatan pertanian. Kondisi lahan yang baik merupakan investasi untuk mendapatkan hasil pertanian yang berlimpah. Namun pengolahan lahan yang benar masih kurang membudaya dikalangan petani. Di pasaran, pupuk organik tersedia dalam berbagai bentuk seperti curah, granul, cair, tablet. Namun, untuk kebutuhan komersial, umumnya pupuk organik padat dibuat dalam bentuk granul. Bentuk granul atau butiran dipilih karena sebagaian besar petani telah terbiasa menggunakan pupuk kimia yang berbentuk granul. Selain itu, pemerintah juga lebih memilih pupuk organik granul sebagai bantuan langsung dan pupuk organik bersubsidi (Sri, Firman, dan Suryanto, 2011). Masalah yang sering terkait dengan adanya limbah pertenakan yaitu salah satu penyebab yang dapat mencemari lingkungan sekitar dan tanah. Limbah peternakan membutuhkan pengelolaan termasuk limbah peternakan sapi atau unggas. Apabila tidak dikelola dengan baik, limbah ini akan berpotensi terhadap pencemaran udara (penguapan amonia dan bau) dan pencemaran air (Machdar dan Izarul, 2018).

Pengelolahan limbah peternakan yang baik dan sanitair mulai dari tahap penimbulan, penyimpanansementara, pengumpulan, pengangkutan, pengolahan, dan pembuangan akhir dapat mencegah timbulnya pencemaran baik udara, air, maupun tanah yang disebabkan oleh sampah selain dapat mencegah terjadinya pencemaran lingkungan juga memberikan nilai tambah terhadap usaha ternak (Kementan, 2010). Feses dapat diolah menjadi produk yang lebih bermanfaat sehingga memiliki nilai ekonomi. Bahkan, limbah dapat dimanfaatkan menjadi produk baru (waste to product) dan menjadi energi (waste to energy). Sebagai contoh, feses binatang ternak bisa dimanfaatkan untuk bahan baku pupuk granul, pupuk organik, pakan ternak, dan biogas (Sri, Firman, dan Suryanto, 2011).

Pupuk organik seperti pupuk kandang ayam merupakan salah satu jenis bahan organik yang memiliki keunggulan dalam menyediakan hara bagi tanaman terutama unsur hara makro dan mikro walaupun dalam jumlah relatif sedikit. Pupuk kandang ayam memiliki kelebihan yang tidak dimiliki pupuk anorganik, yaitu dapat memperbaiki sifat fisik, kimia dan biologi tanah (Kasri dan Adnan, 2015). Menurut Marsono (2013) disebutkan bahwa kandungan kadar hara yang terdapat pada feses ayam yaitu Nitrogen (1\%), Fosfor $(0,80 \%)$, Kalium $(0,40 \%)$, dan Air $(55 \%)$. Kandungan kadar hara pada feses ayam lebih tinggi dibandingkan hewan ternak lainnya karena memiliki Nitrogen, Fosfor, Kalium lebih besar dibandingkan sapi, kambing, babi, kerbau, kuda, sehingga memenuhi persyaratan dalam pembuatan pupuk organik.

Pupuk organik merupakan pupuk yang sebagian atau seluruhnya berasal dari hewan maupun tumbuhan yang berfungsi sebagai penyuplai unsur hara tanah. Dampak yang akan di peroleh dari pemberian pupuk organik tidak hanya peningkatan kandungan C- organik, tetapi akan terjadi juga perbaikan sifat fisik, kimia dan biologi tanah secara keseluruhan. Pupuk organik yang dikembalikan melalui pupuk kandang selain sebagai sumber bahan organik tanah juga sebagai sumber hara bagi pertumbuhan tanaman (Wayan, 2015). Penelitian yang dilakukan Taufaila dkk. (2014) menggunakan kotoran ayam sebagai pupuk organik memperoleh hasil sebagai berikut untuk parameter C-organik $12,23 \%$, parameter $\mathrm{N}$ yaitu $1,77 \%$, parameter $\mathrm{P}$ yaitu $27,45 \%$ dan $\mathrm{K}$ yaitu $3,21 \%$ sehingga semua parameter tersebut sesuai dengan Standar Nasional Indonesia untuk digunakan sebagai pupuk organik kompos. Sedangkan Miftakhul dkk. (2013) diketahui efektivitas kandungan unsur hara pada pupuk kandang hasil fermentasi kotoran ayam memperoleh hasil untuk parameter $\mathrm{N}$ yaitu $0,554 \%$, parameter $\mathrm{C}$ organik yaitu 3,308\% dan untuk parameter $\mathrm{C} / \mathrm{N}$ rasio yaitu 6. Untuk parameter $\mathrm{N}$ memenuhi kriteria Standar Nasional Pupuk Kompos, sedangkan untuk parameter Corganik dan $\mathrm{C} / \mathrm{N}$ rasio tidak memenuhi kriteria Standar Nasional Pupuk Kompos karena memperoleh hasil yang rendah. Berdasarkan uraian diatas maka akan 
dilakukan penelitian pengaruh pemberian dosis EM4 dan dolomit terhadap hasil dari pupuk organik granul dengan menggunakan 3 perlakuan yang berbeda dan masingmasing perlakuan akan dilakukan sebanyak 3 kali pengulangan dengan menggunakan sampel feses ayam yang diambil di Dusun Padeg Kecamatan Cerme Kabupaten Gresik.

\section{METODE}

Penelitian ini dilakukan di
Laboratorium Balai Penelitian dan Konsultasi Industri Surabaya yang dilaksanakan pada bulan September Desember 2018.Pada penelitian ini memanfaatkan limbah feses ayam untuk mengetahui pengaruh pemberian dosis EM4 dan dolomit terhadap hasil dari pupuk organik granul. Sampel feses ayam ini diambil dari peternakan ayam petelur di Dusun Padeg Kecamatan Cerme Kabupaten Gresik.Penelitian ini dilakukan untuk mengetahui pengaruh pemberian dosis EM4 dan dolomit pada hasil dari pupuk organik granul. Rancangan percobaan dalam penelitian ini adalah RAL (rancangan acak lengkap) dengan 4 perlakuan yaitu pemberian dosis EM4 $2 \mathrm{ml} / \mathrm{kg}$ dan $4 \mathrm{ml} / \mathrm{kg}$, serta penambhan dolomit $0,8 \mathrm{gr} / \mathrm{kg}$ dan 0,16 $\mathrm{gr} / \mathrm{kg}$, serta dilakukan sebanyak 3 kali pengulangan. Parameter yang di uji dalam percobaan ini adalah kadar $\mathrm{C} / \mathrm{N}$ rasio, Nitrogen, Phosphat, Kalium, Carbon.

\section{Peralatan dan Bahan Penelitian}

Dalam penelitian ini alat dan bahan yang digunakan adalah:

\section{a. Alat}

Wadah bekas berjumlah 12 buah, gelas ukur untuk mengukur EM4 yang diencerkan dengan air yang ada pada aturan di botol EM4 yaitu 1:50, bascom untuk menghomogenkan EM4 yang di larutkan menggunakan air sesuai perbandingan pada aturan botol EM4, centong untuk mengaduk pada proses fermentai pengomposan di setiap harinya, hygrometer untuk mengukur kelembaban dan suhu secara fisik pada setiap harinya. b. Bahan

EM4, Dolomit, Limbah peternakan feses ayam yang diambil di Dusun Padeg Kecamatan Cerme Kabupaten Gresik.

Dalam peneliian ini variabel yang akan digunakan adalah EM4 dan dolomit, Penelitian ini dilakukan untuk mengetahui pengaruh pemberian dosis EM4 dan dolomit pada hasil dari pupuk organik granul dengan 4 perlakuan serta pada masing-masing perlakuan akan dilakuakan pengulangan sebanyak 3 kali. Untuk Variabel bebas dalam penelitian ini adalah variasi jenis media untuk membuat pupuk organik granul sebagai berikut:

1. Pada perlakuan pertama menggunakan sampel feses ayam sebanyak $1 \mathrm{~kg}$ dengan pemberian dosisi EM4 2ml $/ \mathrm{kg}$ dan penambahan dolomit $0,8 \mathrm{gr} / \mathrm{kg}$ yang akan dilakuakan 3 kali pengulangan.

2. Pada perlakuan kedua menggunakan sampel feses ayam sebanyak $1 \mathrm{~kg}$ dengan pemberian dosisi EM4 $4 \mathrm{ml} / \mathrm{kg}$ dan penambahan dolomit $0,8 \mathrm{gr} / \mathrm{kg}$ yang akan dilakuakan 3 kali pengulangan.

3. Pada perlakuan ketiga menggunakan sampel feses ayam sebanyak $1 \mathrm{~kg}$ dengan pemberian dosisi EM4 $2 \mathrm{ml} / \mathrm{kg}$ dan penambahan dolomit $1,6 \mathrm{gr} / \mathrm{kg}$ yang akan dilakuakan 3 kali pengulangan.

4. Pada perlakuan keempat menggunakan sampel feses ayam sebanyak $1 \mathrm{~kg}$ dengan pemberian dosisi EM4 4ml $/ \mathrm{kg}$ dan penambahan dolomit 1,6 gr/kg yang akan dilakuakan 3 kali pengulangan.

Dan untuk variabel terikat dalam penelitian ini adalah kualitas pupuk organik granul yang berbahan dasar feses ayam. Berdasarkan parameter yang di teliti yaitu $\mathrm{C} / \mathrm{N}$ rasio, $\mathrm{N}, \mathrm{P}, \mathrm{K}$, dan $\mathrm{C}$ organik yang akan disesuaikan dengan Permentan No.70/Permentan/SR.140/10/2011.

Populasi dan penentuan sampel dalam penelitian ini adalah populasi sampel feses ayam yang diambil di Dusun Padeg Kecamatan Cerme Kabupaten Gresik. Sampel dalam penelitian ini adalah Feses ayam yang diambil sebanyak $13 \mathrm{~kg}$ untuk di proses kembali menjadi pupuk organik granul 
HASIL DAN PEMBAHASAN

Hasil uji karakteristik awal feses ayam sebelum dilakukan pengolahan dapat dilihat pada Tabel 1.

Tabel 1. Hasil Uji Karakteristik Feses Ayam

\begin{tabular}{ccc}
\hline No & Parameter & Hail Laboratorium \\
\hline 1. & Nitrogen & $1,74 \%$ \\
2. & Kalium & $2,99 \%$ \\
3. & Phosphor & $1,51 \%$ \\
4. & Carbon & $12.08 \%$ \\
5. & C/N rasio & $9,85 \%$ \\
\hline
\end{tabular}

Setelah dilakukan penelitian secara Setelah dilakukan penelitian secara kuantitatif mengenai pengaruh pemberian dosis EM4 dan dolomit terhadap hasil dari pupuk organik granul dengan parameter nitrogen, karbon, phosphor, kalium dan $\mathrm{C} / \mathrm{N}$ rasio dari limbah feses ayam sebelum diolah, maka didapatkan hasil yaitu pada parameter Nitrogen 2,75\%, Phosphat $1,84 \%$, Kalium 2,51\%, Carbon 27,12\% dan $\mathrm{C} / \mathrm{N}$ rasio 9,85. Dapat diketahui bahwa karakteristik feses ayam sebelum dilakukan pengomposan kadar paling tinggi yaitu pada parameter Carbon $27,17 \%$ sedangkan kadar paling rendah yaitu pada parameter Phospor $1,84 \%$. Unsur hara N, P, dan K sangat di perlukan untuk pembuatan kompos, sehingga parameter tersebut memungkinkan sebagai bahan baku untuk memebuat kompos yang akan dijadikan pupuk organik granul.

Hasil uji karakteristik kualitas pupuk organik granul mengenai pengaruh pemberian dosis EM4 dan Dolomit Pada Keempat Perlakuan dapat dilihat pada Tabel 2.

\section{Tabel 2. Hasil Uji Karakteristik kualitas Pupuk Organik Granul Dengan Penambahan EM4 dan Dolomit pada keempat perlakuan}

\begin{tabular}{cccccc}
\hline $\begin{array}{c}\text { Perlakua } \\
\text { n }\end{array}$ & $\begin{array}{c}\text { Pertam } \\
\mathbf{a}\end{array}$ & Kedua & Ketiga & $\begin{array}{c}\text { Keempa } \\
\mathbf{t}\end{array}$ & $\begin{array}{c}\text { Baku } \\
\text { Mutu* }\end{array}$ \\
\hline Nitrogen & $1,79 \%$ & $1,52 \%$ & $1,74 \%$ & $1,76 \%$ & $<6$ \\
Phosphat & $4,73 \%$ & $3,76 \%$ & $2,99 \%$ & $5,28 \%$ & $<6$ \\
Kalium & $1,38 \%$ & $1,12 \%$ & $1,51 \%$ & $1,5 \%$ & $<6$ \\
Carbon & $29,8 \%$ & $25,4 \%$ & $12.08 \%$ & $11,20 \%$ & $>15$ \\
C/N rasio & 16,68 & 17,75 & 6.95 & 6,32 & $15-25$ \\
\hline
\end{tabular}

Dapat diketahui hasil dari karakteristik kualitas pupuk organik granul dengan penambahan EM4 $2 \mathrm{ml} / \mathrm{kg}$ dan dolomit 0,8 gram $/ \mathrm{kg}$ pada perlakuan pertama didapatkan hasil untuk parameter Nitrogen yaitu $1,79 \%$, Phosphor $4,73 \%$, Kalium $1,38 \%$, Karbon 29,8\%, dan $\mathrm{C} / \mathrm{N}$ rasio 16,68. Pada perlakuan kedua hasil dari karakteristik kualitas pupuk organik granul dengan penambahan EM4 $4 \mathrm{ml} / \mathrm{kg}$ dan dolomit $0,8 \mathrm{gram} / \mathrm{kg}$ mendapatkan hasil rata-rata untuk parameter Nitrogen $1,52 \%$, Phosphor 3,76\%, Kalium 1,12\%, Karbon $25,4 \%$, dan $\mathrm{C} / \mathrm{N}$ rasio 17,75 . Untuk karakteristik kualitas pupuk organik granul yang ada di perlakuan ketiga dengan penambahan EM4 2ml/kg dan dolomit 1,6 gram $/ \mathrm{kg}$ memperoleh hasil untuk parameter Nitrogen 1,74\%, Phosphor2,99\%, Kalium $1,51 \%$, Karbon $12,08 \%$, dan $\mathrm{C} / \mathrm{N}$ rasio 6,95. Sedangkan karakteristik kualitas pupuk organik granul pada perlakuan keempat dengan penambahan EM4 $4 \mathrm{ml} / \mathrm{kg}$ dan dolomit 1,6 gram/kg didapatkan hasil rata-rata untuk parameter Nitrogen 1,76\%, Phosphor 5,28\%, Kalium 1,5\%, Karbon $11,20 \%$, dan $\mathrm{C} / \mathrm{N}$ rasio 6,32. Dan dari hasil karakteristik kualitas pupuk organik granul tersebut akan disesuaikan dengan melihat 
syarat standart permentan No. 70 tahun 2011.

\section{HASIL DAN PEMBAHASAN}

Dari hasil dari deskripsi diatas, terlihat bahwa feses ayam yang belum dilakukan perlakuan dengan parameter nitrogen, karbon, phosphor, kalium, dan $\mathrm{C} / \mathrm{N}$ Rasio masih tinggi hal ini karena menurut Musnawar (2003), kotoran ayam mengandung unsur hara lengkap yang dibutuhkan oleh tanaman untuk pertumbuhannya seperti nitrogen $(\mathrm{N})$, fosfor $\left(\mathrm{P}_{2} \mathrm{O}_{5}\right)$ dan kalium $\left(\mathrm{K}_{2} \mathrm{O}\right)$. Kandungan kadar hara pada feses ayam lebih tinggi dibandingkan hewan ternak lainnya karena memiliki Nitrogen, Fosfor, Kalium lebih besar dibandingkan sapi, kambing, babi, kerbau, kuda, sehingga memenuhi persyaratan dalam pembuatan pupuk organik.

Pada sampel feses ayam dengan dosis EM4 sebanyak $2 \mathrm{ml} / \mathrm{kg}$ dan dolomit sebanyak $0,8 \mathrm{gr} / \mathrm{kg}$ hasil dari parameter nitrogen dengan rerata $1,79 \%$, karbon memperoleh rerata $29,8 \%$, phosphor memperoleh rerata $4,73 \%$, kalium $1,38 \%$ dan $\mathrm{C} / \mathrm{N}$ Rasio memperoleh rerata 16,68 dengan 3 kali replikasi menunjukkan hasil yang memenuhi syarat sesuai dengan permentan no 70 tahun 2011 yang menjelaskan bahwa baku mutu nitrogen, phosphor dan kalium sebesar $<6 \%$, karbon $>15 \%$ dan C/N Rasio memiliki baku mutu sebesar 15-25. Hal ini menunjukkan bahwa pupuk organik granul bisa dijadikan sebagai pupuk untuk tanaman. Unsur hara makro dan mikro sangat dibutuhkan untuk pertumbuhan tanaman. Fungsi unsur hara makro diantaranya Nitrogen $(\mathrm{N})$, berfungsi merangsang pertumbuhan tanaman secara keseluruhan, untuk sintesa asam amino dan protein dalam tanaman Merangsang pertumbuhan vegetatif (warna hijau daun, panjang daun, lebar daun) dan pertumbuhan vegetatif batang (tinggi dan ukuran batang). Phospat $\left(\mathrm{P}_{2} \mathrm{O}_{5}\right)$ berfungsi untuk pengangkutan energi hasil metabolisme dalam tanaman, merangsang pembungaan dan pembuahan, merangsang pertumbuhan akar, merangsang pembentukan biji, merangsang pembelahan sel tanaman dan memperbesar jaringan sel. Kalium $\left(\mathrm{K}_{2} \mathrm{O}\right)$ berfungsi dalam proses fotosintesa, pengangkutan hasil asimilasi, enzim dan mineral termasuk air. Meningkatkan daya tahan/kekebalan tanaman terhadap penyakit. Meningkatkan kapasitas tukar kation (KTK) tanah dan membentuk senyawa kompleks dengan ion logam yang meracuni tanaman seperti aluminium, besi, dan mangan (Campbell, 2005).

Hasil penelitian pada sampel feses ayam dengan dosis EM4 4ml $/ \mathrm{kg}$ dan dolomit $0.8 \mathrm{gr} / \mathrm{kg}$ menunjukkan bahwa nitrogen memperoleh rerata $1,52 \%$, phosphor memperoleh rerata $3,76 \%$, kalium memperoleh rerata $1,12 \%$, karbon $25,4 \%$, dan C/N Rasio memperoleh 17,75. Hal ini menunjukkan bahwa semua parameter yg di teliti telah memenuhi syarat sesuai dengan permentan no 70 tahun 2011 yang menjelaskan bahwa baku mutu nitrogen, phosphor dan kalium sebesar $<6 \%$, karbon $>15 \%$ dan C/N Rasio memiliki baku mutu sebesar 15-25. Dapat disimpulkan bahwa dosis EM4 4ml/kg dengan dolomit 0,8 $\mathrm{gr} / \mathrm{kg}$ merupakan dosis yang tepat untuk pembuatan pupuk organik granul. Menurut Pangaribuan et al. (2012), pupuk kandang ayam memiliki kandungan unsur hara $\mathrm{N}, \mathrm{P}$ dan $\mathrm{K}$ yang lebih banyak dari pada pupuk kandang jenis ternak lainnya karena kotoran padat pada ternak unggas tercampur dengan kotoran cairnya. Semakin besar kandungan unsur $\mathrm{N}, \mathrm{P}$, dan $\mathrm{K}$ dalam pupuk, maka akan berdampak sangat baik bagi tanaman yang dipupuk. Selain itu mengandung nitrogen dan phosphor yang cukup tinggi pada kompos kotoran ayam juga mengandung kalium yang tinggi, yang berperan sebagai aktifator enzim dalam metabolisme karbohidrat dan nitrogen yang meliputi pembentukan, pemecahan dan translokasi pati, serta berpengaruh terhadap pengangkutan fosfor. Pada proses fotosintesis kalium secara langsung memacu pertumbuhan dan indeks luas daun, sehingga meningkatkan asimilasi $\mathrm{CO}_{2}$ serta meningkatkan translokasi produk fotosintesis. Menurut Subhan et al. (2008) bokashi yang berasal dari kotoran ayam mengandung sejumlah unsur hara dan bahan organik yang dapat memperbaiki 
sifat fisik, kimia, dan biologi tanah. Ketersediaan hara dalam tanah, struktur tanah dan tata udara tanah yang baik sangat mempengaruhi pertumbuhan dan perkembangan akar serta kemampuan akar tanaman dalam menyerap unsur hara. Kalium juga berperan dalam memperkuat tubuh tanaman agar daun, bunga dan buah tidak mudah gugur. Kalium merupakan sumber kekuatan bagi tanaman dalam menghadapi kekeringan dan penyakit (Marsono, 2007).

Dari hasl penelitian dengan sampel feses ayam sebanyak $1 \mathrm{~kg}$, menggunakan EM4 2ml/kg dan dolomit 1.6 gram $/ \mathrm{kg}$ memperoleh hasil yaitu pada parameter nitrogen memperoleh rerata $1,74 \%$, phosphor memperoleh rerata yaitu 2.99\% dan kalium memperoleh rerata $1,51 \%, 3$ parameter tersebut memenuhi syarat sesuai dengan permentan no 70 tahun 2011 yaitu untuk parameter nitrogen, phosphat dan kalium tidak boleh $>6 \%$, sedangkann hasil laboratorium untuk parameter carbon memperoleh rerata $12,08 \%$ dan $\mathrm{C} / \mathrm{N}$ Rasio memperoleh rerata yaitu 6.95 , kedua parameter tersebut tidak memenuhi persyaratan permentan no 70 tahun 2011 yang menyebutkan bahwa untuk parameter carbon minimal 15\% sedangkan untuk parameter C/N Rasio minimal 15-25. Dari hasil penelitian tersebut terlihat bahwa kandungan $\mathrm{C} / \mathrm{N}$ Rasio yang tidak memenuhi syarat. Penururnan $\mathrm{C} / \mathrm{N}$ Rasio ini disebabkan karena terjadi penurunan karbon yang dipakai sumber energi mikroba untuk menguraikan atau mendekomposisi material organil. Selama proses pengomposan $\mathrm{CO}_{2}$ menguap dan menyebabkan penurunan kadar karbon $(\mathrm{C})$ dan peningkatan kadar nitrogen (N) sehingga rasio $\mathrm{C} / \mathrm{N}$ kompos menurun. Salah satu aspek yang paling penting dari keseimbangan hara total adalah rasio organik karbon dengan nitrogen $(\mathrm{C} / \mathrm{N})$. Rasio $\mathrm{C} / \mathrm{N}$ bahan organik adalah perbandingan antara banyaknya kandungan unsur karbon (C) terhadap banyaknya kandungan unsur nitrogen yang ada pada suatu bahan organilk. Jika $\mathrm{C} / \mathrm{N}$ rasio tinggi, aktivitas biologi mikroorganisme akan berkurang, diperlukan beberapa siklus mikroorganisme untuk mendegradasi kompos sehingga diperlukan waktu yang lama untuk pengomposan dan dihasilkan mutu yang lebih rendah, jika C/N Rasio terlalu rendah kelebihan nitrogen yang tidak dipakai oleh mikroorganisme tidak dapat di asimilasi dan akan hilang melalui volatisasi sebagai amoniak atau terdentrifikasi (Djuarnani, 2005).

Hasil penelitian pada sampel feses ayam $1 \mathrm{~kg}$ dengan dosis EM4 $4 \mathrm{ml} / \mathrm{kg}$ dan dolomit 1,6 gram $/ \mathrm{kg}$ yaitu pada parameter nitrogen memperoleh rerata $1,76 \%$, phosphor memperoleh rerata yaitu 5,28\%, untuk parameter kalium memperoleh rerata $1,5 \%$, parameter karbon memperoleh rerata $11,20 \%$ dan untuk parameter $\mathrm{C} / \mathrm{N}$ rasio memperoleh rerata 6,32. Untuk parameter nitrogen, phosphor dan kalium memperoleh hasil yang memenuhi syarat sesuai permentan no 70 tahun 2011 yaitu untuk ketiga parameter tersebut mempunyai standar maksimal 6\%. Sedangkan untuk parameter karbon menurut permentan no 70 tahun 2011 mempunyai standar minimal $15 \%$ sedangkan hasil penelitian memperoleh $11,20 \%$ yang artinya hasil tersebut tidak memenuhi persyaratan. Untuk parameter $\mathrm{C} / \mathrm{N}$ rasio memperoleh hasil 6,32 sedangakan menurut permentan no 70 tahun 2011 standar parameter tersebut yaitu 15-25 yang artinya untuk parameter $\mathrm{C} / \mathrm{N}$ rasio tidak memenuhi persyaratan. Unsur hara makro dan mikro sangat dibutuhkan untuk pertumbuhan tanaman. Fungsi unsur hara makro diantaranya Nitrogen $(\mathrm{N})$, berfungsi merangsang pertumbuhan tanaman secara keseluruhan, untuk sintesa asam amino dan protein dalam tanaman. Merangsang pertumbuhan vegetatif (warna hijau daun, panjang daun, lebar daun) dan pertumbuhan vegetatif batang (tinggi dan ukuran batang). Phospat $\left(\mathrm{P}_{2} \mathrm{O}_{5}\right)$ berfungsi untuk pengangkutan energi hasil metabolisme dalam tanaman, merangsang pembungaan dan pembuahan, merangsang pertumbuhan akar, merangsang pembentukan biji, merangsang pembelahan sel tanaman dan memperbesar jaringan sel. Kalium (K) berfungsi dalam proses fotosintesa, pengangkutan hasil asimilasi, enzim dan mineral termasuk air. Meningkatkan daya tahan/kekebalan tanaman terhadap 
penyakit. Meningkatkan kapasitas tukar kation (KTK) tanah dan membentuk senyawa kompleks dengan ion logam yang meracuni tanaman seperti aluminium, besi, dan mangan (Campbell, 2005). Dari data tersebut dapat dilihat bahwa kandungan menurun. Hal ini disebabkan karena selama pengomposan bakteri memanfaatkan senyawa karbon sebagai sumber energi dalam metabolisme dan perbanyakan sel yang diubah menjadi asam - asam organik dan alkohol terlebih dahulu kemudian diubah menjadi $\mathrm{CO}_{2}, \mathrm{CH}_{4}$, dan $\mathrm{H} 2 \mathrm{O}$ (Dipo Yuwono, 2006). Nilai C/N kompos (produk) yang semakin besar menunjukkan bahwa bahan organik belum terdekomposisi sempurna. Sebaliknya nilai $\mathrm{C} / \mathrm{N}$ kompos yang semakin rendah menunjukkan bahwa bahan organik sudah terdekomposisi dan hampir menjadi kompos. Menurut Isroi (2008) Pada nilai $\mathrm{C} / \mathrm{N}$ di antara $30-40$ mikroba mendapatkan cukup $\mathrm{C}$ untuk energi dan $\mathrm{N}$ untuk sintesis protein. Apabila nilai $\mathrm{C} / \mathrm{N}$ terlalu tinggi, mikroba akan kekurangan $\mathrm{N}$ untuk sintesis protein sehingga dekomposisi berjalan lambat. Pada kompos dengan kandungan rasio $\mathrm{C} / \mathrm{N}$ rendah akan banyak mengandung amoniak (NH3) yang dihasilkan oleh bakteri amoniak. Senyawa ini dapat dioksidasi lebih lanjut menjadi nitrit dan nitrat yang mudah diserap oleh tanaman. Perbandingan $\mathrm{C} / \mathrm{N}$ terlalu rendah juga akan menyebabkan terbentuknya gas amoniak, sehingga nitrogen mudah hilang ke udara (Harada et all., 1993).

\section{KESIMPULAN}

Dari penelitian yang telah dilakukan tentang pengaruh pemberian dosis EM4 dan dolomit terhadap hasil dari pupuk organik granul dapat disimpulkan bahwa pada perlakuan pertama yaitu sampel feses ayam sebanyak $1 \mathrm{~kg}$ dengan dosis EM4 2ml/kg dan dolomit $0,8 \mathrm{gr} / \mathrm{kg}$ untuk parameter Nitrogen dan Carbon memperoleh hasil yang lebih tinggi dibandingkan perlakuan kedua, ketiga, keempat dan untuk parameter Phosphor, Kalium dan $\mathrm{C} / \mathrm{N}$ rasio pada perlakuan peertama memperoleh hasil yang memenuhi sayarat sesuai dengan permentan No. 70 tahun 2011. Pemberian dosis EM4 dan Dolomit yang paling berpengaruh terhadap hasil pupuk organik granul yaitu pada perlakuan pertama, Kemudian pada perlakuan kedua memang memenuhi standar permentan tetapi memperoleh hasil lebih rendah dibandingkan dengan perlakuan pertama, sedangkan untuk perlakuan ketiga dan keempat tidak berpengaruh terhadap pupuk organik granul karena pada parameter carbon dan $\mathrm{C} / \mathrm{N}$ rasio memperoleh nilai dibawah standar permentan No. 70 tahun 2011.Pada perlakuan pertama dan kedua memberikan hasil yang memenuhi syarat sesuai dengan permentan No. 70 tahun 2011, sedangkan perlakuan ketiga dan keempat untuk parameter Carbon dan $\mathrm{C} / \mathrm{N}$ rasio tidak memenuhi persyaratan sesuai dengan standar permentan No. 70 tahun 2011, Oleh karena itu diharapkan pada penelitian ini dapat dilanjutkan dan dikembangkan oleh peneliti selanjutnya agar pupuk organik granul dapat diolah dengan dosis yang tepat agar sesuai dengan Permentan No 70 Tahun 2011.

\section{UCAPAN TERIMA KASIH}

Ucapan terima kasih disampaikan kepada kepala Laboratorium Teknik Lingkungan yang telah banyak membantu dalam penelitian dan menyediakan alat dan bahan penelitian serta ke UPT Laboratorium DLH Provinsi Jawa Timur. 


\section{DAFTAR PUSTAKA}

Argo et all. (2012). Optimasi Penambahan Unsur Hara NPK pada Limbah Biogas dan Kompos Kambing Sebagai Bahan Pembuatan Pupuk Organik Granul dengan Menggunakan Progam Linier. Jurnal Teknologi Pertanian

Djuarnani. (2005). Cara Cepat Membuat Kompos. Jakarta. Agro Media Pustaka. Indriani. (2000). Membuat Kompos Secara Kilat. Jakarta. Penebar Swadaya. Isroi. (2008). Kompos. Bogor, Balai Penelitian Bioteknologi Perkebunan Indonesia.

Kementrian Pertanian. (2010). Petunjuk Praktis Manajemen Umum Limbah Ternak untuk Kompos dan Biogas. NTB, Balai Pengkajian Teknologi Pertanian.

Marsono dan Lingga. (2013). Petunjuk Penggunaan Pupuk. Jakarta. Penebar Swadaya.

Mulyono. (2014). Membuat MOL dan Kompos dari Sampah Rumah Tangga. PT. Agromedia Pustaka. Jakarta Selatan.

Notoatmodjo. (2012). Metodologi Penelitian Kesehatan. Jakarta. Rineka Cipta.

Nugroho. (2013). Panduan Membuat Pupuk Kompos Cair. Yogyakarta. Pustaka baru press.

Pengaribuan, Yasir, dan Utami. (2012). Dampak Bokashi Kotoran Ternak dalam Pengurangan Pemakaian Pupuk Anorganik pada Budidaya Tanaman Tomat.Indonesia. J. Agron.

Peraturan Menteri Pertanian Nomor 70/permentan/SR.140/10/2011 Tentang Pupuk Organik Granul dari Aneka Limbah.

Permata, dkk. (2014). Pemanfaatan Limbah Kulit Ari Keledai dari Industri Rumahan Tempe menjadi Pupuk Granul. Gema Kesehatan Linkungan.

Rosmarkan, Afandie, dan Nasih. (2002). Ilmu Kesuburan Tanah. Yogyakarta. kamisius (Anggota IKAPI).

Sriharti. (2008). Pemanfaatan Limbah Pisang Untuk Pembuatan Pupuk Kompos Menggunakan Kompos Rotary Drum. Yogyakarta. Prosising Seminar Nasional Bidang Teknik Kimia dan Tekstil.

Subhan, Hamzah, dan Wahab. (2008). Aplikasi bokashi kotoran ayam pada tanaman melon. Jurnal Agrisistem.

Sudiarto. (2008). "Pengelolaan Limbah Terpadu dan Agribisnis yang Berwawasan Lingkungan". Bandung, Seminar Nasional Teknologi Peternakan dan Veteriner, 5260 .

Wahyono, dkk. (2011). Membuat Pupuk Organik Granul dari Aneka Limbah. Jakarta. Argo Media Pustaka.

Widodo. (2008). Kotoran (Tai) Ayam. http://www.organikilo.co/2014/12/ kandunganunsur-hara-kotoran-sapi-htm.

Winarso. (2005). Kesuburan Tanah: Dasar Kesehatan dan Kualitas Tanah, Gava Media. Yogyakara.

Yuliarti dan Nurheti. (2009). 1001Cara Menghasilkan Pupuk Organik. Yogyakarta. Lily Publisher.

Yuwono. (2006). Kompos. Jakarta. Penebar Swadaya

Campbell. (2010). Meningkatkan Kapasitas Tukar Kation (KTK) Tanah dan Membentuk Senyawa Kompleks Dengan Ion Logam YangMeracuni Tanaman.Jakarta. Kloepper.

Widarti, Wardhini, dan Sarwono. (2015). Pengaruh Rasio C/N Bahan Baku Pada Pembuatan Kompos Dari Kubis Dan Kulit Pisang. Samarinda. Gunung Kelua, 5(2), 75-80.

Purnomo, Sutrisno, dan Sumiyati. (2017). Pengaruh Variasi C/N Rasio Terhadap Produksi Kompos Dan Kandungan Kalium (K), Pospat (P) Dari Batang Pisang Dengan Kombinasi Kotoran Sapi Dalam Sistem Vermicomposting. Semarang. Indonesia. 